\title{
Suomalais-unkarilaista aikuiskasvatusta
}

Unkarilaisia ja suomalaisia aikuiskasvattajia oli koolla 13.-15. kesäkuuta Kajaanin upouudessa Kaukametsä -salissa. Maiden välisen kulttuurivaihtosopimuksen mukaisesti kokoonnuttiin nyt toisen kerran. Ensimmäinen symposium pidettiin neljä vuotta sitten Sopronissa.

Kansanvalistusseura ja Aikuiskasvatuksen Tutkimusseura toimivat symposiumin järjestäjinä. Kajaanin kaupungin kansalaisopisto vastasi paikallisista järjestelyistä ja alueen muut aikuisoppilaitokset avustivat avaamalla ovensa tutustumista varten.

Unkarilaisten valtuuskuntaa johtivat varaministeri Ferenc Rátkai ja sivistysasiain ministeriön osastopäällikkö Sándor Kormos. Molemmista maista mukana oli sekä hallinnon että tutkimuksen edustajia, mutta myös käytännön aikuiskasvattajia.

Symposiumin ohjelma oli rakennettu siten, että kustakin aiheesta oli sekä unkarilainen että suomalainen puheenvuoro. Aihepiireinä olivat aikuiskasvatuksen kehitys edellisen symposiumin jälkeen, valtion ja kansalaisen suhde aikuiskasvatuksessa, luonnontieteet aikuiskasvatuksessa sekä nuorten sosialisaatio ja aikuiskasvatus. Suomalaiset alustajat olivat: opetusministeriön kansliapäällikkö Jaakko Nurminen, Vapaan sivistystyön yhteisjärjestön pääsihteeri Timo Toiviainen, aikuiskasvatuksen apulaisprofessori Jukka Tuomisto, biologian professori Mikko Raatikainen sekä fil.toht. Helena Helve.

Seuraavassa esitellään keskeisiä kohtia Debrecenin yliopiston aikuiskasvatuksen professori Pál Sóosin sekä toht. László Köpfin alustuksista. Lisäksi unkarilaisista esiintyivät Tieteellisen valistusjärjestön (TIT) luonnontieteellisen studion johtaja Agnes Juhász Nagy sekä sivistysasiain ministeriön virkailija Judit Egyed.

Prof. Pál Sóosin teemana oli Uusi tilanne uudet vaatimukset Unkarin aikuiskoulutuksessa. Toht. László Köpf puolestaan käsitteli alustuksessaan valtion ja kansalaisen roolia aikuiskasvatuksessa. Molempiin puheenvuoroihin heijastui voimakkaasti Unkarin yhteiskunnallinen tilanne.

Prof. Sóos erotti kolme ratkaisumallia Unkarin yhteiskunnan ongelmiin:
1. Asteittain voimaan saatettavat talouspoliittiset uudistukset.

2. Poliittinen rakenteen uudistaminen koskematta kuitenkaan sosialistiseen perusrakenteeseen.

3. Tieteen, opetuksen ja kulttuurin uudistaminen.

Eri ratkaisumalleilla on omat kannattajansa. Unkarissa sekä opetusala että kulttuurityö lasketaan nk. tuottamattomaan työhön, joka on merkinnyt kasvavia rahoitusvaikeuksia, mutta myös koulutuksen ja kulttuurin arvostuksen laskua.

Kohtalokkaimmaksi talouspoliittinen tuottamattoman työn periaate on osoittautunut koululaitoksen kohdalla. Koulujen rakentaminen ei ole seurannut demografisia muutoksia, keskusjohtoinen suunnittelu ei ole osannut arvioida opettajainkoulutustarvetta, opetussuunnitelmat ja oppikirjat ovat kaavamaisia ja ikäviä, opettajien yhteiskunnallinen asema on huono.

Aikuiskasvatuksen tilanne on samantapainen, vaikka erojakin on. 1960-luvulla kirjastojen käyttäjämäärät kasvoivat ja taiteen harrastus lisääntyi sekä kulttuuritaloverkosto laajeni. Koulututkintoihin tähtäävästä aikuisopetuksesta, poliittisesta kasvatuksesta ja tieteen popularisoinnista kiinnostuneiden luku kohosi satoihin tuhansiin. Kasvu pysähtyi kuitenkin pian ja opiskelijamäärät alkoivat laskea. Osasyynä esim. koulututkintoon tähtäävien opiskelijoiden määrän pienenemiseen oli peruskoulutustason nousu, mutta myös tiedon ja osaamisen arvostuksen yleinen väheneminen.

Aikuisten ammatti- ja jatkokoulutuskursseja on koko 80-luvun vaivannut stagnaatio. Työvoiman "hallittu" siirtyminen uusille aloille olisi elintärkeää, mutta nykyinen koulutusjärjestelmä ei toht. Köpfin mukaan pysty vastaamaan haasteeseen.

Kulttuurin ja koulutuksen uudistuspyrkimykset nousevat nyt sisäisestä demokratisoitumisesta ja taloudellisen rakenteen nykyaikaistamisen pakosta. Näyttämölle on astunut sukupolvi, johon Stalinin "valtiososialistinen malli" ei enää vaikuta. Kansalaisten aktiivisuus on 
saanut uusia muotoja. Esimerkiksi kansanopistoja ${ }^{\prime \prime}$ on perustettu paikallisten aloitteiden pohjalta. Eri puolilla maata on syntynyt myös asukas- ja harrastuskerhoja sponttaanisesti. Kerhot ja ryhmät toimivat itsenäisesti, vaikka ne olisikin liitetty muodollisesti johonkin organisaatioon.

Realistisen kuvan säilyttämiseksi on kuitenkin muistettava, että samalla kertaa, kun kansalaiset ovat aktivoituneet, taloudelliset toimintaedellytykset ovat huonontuneet. Lisäksi ylitöissä puurtavilla unkarilaisilla on nykyään vähemmän aikaa ja rahaa käytettäväksi kulttuuriin ja opiskeluun.

Kuten edellä referoidusta käy ilmi Unkarin yhteiskuntapoliittinen tilanne heijastui voimakkaasti symposiumin puheenvuoroihin. Se millaisen suunnan talous- ja yhteiskuntapolitiikka saavat, koettiin selvästi viitoittavan myös aikuiskasvatuksen tulevaisuutta. Unkarin avoin keskusteluilmapiiri toteutui myös Kajaanissa. Ongelmat tuotiin esille selväsanaisesti, keskustelu oli vilkasta ja siinä esitettiin erilaisia mielipiteitä. Kun Sopronin symposium neljä vuotta sitten oli pitkälti tutustumista kummankin maan aikuiskasvatusjärjestelmään, päästiin Ka- jaanissa askelen pidemmälle. Siitä on seuraavalla kerralla hyvä jatkaa.

Silloin tällöin kuulee epäileviä huomautuksia tällaisten symposiumien hyödyllisyydestä. Onko meillä jotakin oppimista Unkarin aikuiskasvatuksesta? Vaikka yhteiskuntiemme perusrakenteet ovat erilaiset ja siitä johtuen myös koulutusorganisaatiot poikkeavat toisistaan, on monia alueita, jossa järjestelmät eivät ole ratkaisevia. Tällaisia ovat esimerkiksi oppimiseen ja osallistumiseen liittyvät kysymykset. Lisäksi jokaisen maan aikuiskasvatuksessa on löydettävissä omaperäisiä, ideoita antavia ratkaisuja. Unkarissa tällainen alue on aikuisten luonnontieteellinen opetus. Kolmanneksi: kansainvälisessä seuraassa pystyy omaa työtään parhaiten tarkkailemaan ulkoapäin. Oman työn olennaisuudet selkiytyvät toisella tavalla kuin istumalla kirjoituspöydän takana. Joten: tervemenoa vuonna 1992 Unkariin!

\footnotetext{
1)Unkarilainen kansanopisto ei ole internaatti, vaan muistuttaa pikemminkin suomalaista kansalaisopistoa.
}

Marja-Liisa Putkonen 